Article

\title{
The Impact of Removal of Ovarian Hormones on Cholinergic Muscarinic Receptors: Examining Prepulse Inhibition and Receptor Binding
}

\author{
Sarah S. Ch'ng ${ }^{1,+}$, Adam J. Walker ${ }^{1,2,+}$, Madeleine McCarthy ${ }^{1}$, Thien-Kim Le ${ }^{1,3}$, \\ Natalie Thomas ${ }^{1,4}\left(\mathbb{D}\right.$, Andrew Gibbons ${ }^{1,4}$, Madhara Udawela ${ }^{1,3}{ }^{\oplus}$, Snezana Kusljic ${ }^{1,5}$, \\ Brian Dean ${ }^{1,6}$ and Andrea Gogos ${ }^{1, *}$ \\ 1 Florey Institute of Neuroscience and Mental Health, University of Melbourne, Parkville, VIC 3010, Australia; \\ sarah.chng@florey.edu.au (S.S.C.); a.walker@deakin.edu.au (A.J.W.); \\ madeleine.mccarthy@florey.edu.au (M.M.); thien-kim.le@affinitybio.com.au (T.-K.L.); \\ natalie.thomas@monash.edu (N.T.); andrew.gibbons@monash.edu (A.G.); \\ madhara.udawela@affinitybio.com.au (M.U.); skusljic@unimelb.edu.au (S.K.); \\ brian.dean@florey.edu.au (B.D.) \\ 2 IMPACT, The Institute for Mental and Physical Health and Clinical Translation, School of Medicine, Deakin \\ University and Barwon Health, Geelong, VIC 3220, Australia \\ 3 Affinity BIO, Scoresby, VIC 3179, Australia \\ 4 Department of Psychiatry, Monash University, Melbourne, VIC 3004, Australia \\ 5 Department of Nursing, University of Melbourne, Parkville, VIC 3010, Australia \\ 6 Centre for Mental Health, Swinburne University, Hawthorn, VIC 3122, Australia \\ * Correspondence: andrea.gogos@florey.edu.au \\ + These authors contributed equally to this work.
}

Received: 22 January 2020; Accepted: 13 February 2020; Published: 17 February 2020

check for updates

\begin{abstract}
Ovarian hormones, such as estrogens and progesterone, are known to exert beneficial effects on cognition and some psychiatric disorders. The basis of these effects is not fully understood, but may involve altered cholinergic neurotransmission. This study aimed to investigate how a lack of ovarian hormones would impact muscarinic receptor-induced deficits in prepulse inhibition (PPI) and muscarinic receptor density in several brain regions. Adult female rats were either ovariectomized, to remove the source of ovarian hormones, or left intact (sham-operated). PPI is a measure of sensorimotor gating that is typically impaired in schizophrenia patients, and similar deficits can be induced in rats by administering scopolamine, a muscarinic receptor antagonist. Our results revealed no significant effects of ovariectomy on PPI after saline or scopolamine treatment. Autoradiography was performed to measure cholinergic muscarinic receptor binding density using $\left[{ }^{3} \mathrm{H}\right]$-pirenzepine, $\left[{ }^{3} \mathrm{H}\right]-A F-D X$, and $\left[{ }^{3} \mathrm{H}\right]-4-D A M P$, to label $\mathrm{M}_{1}, \mathrm{M}_{2} / \mathrm{M}_{4}$, and $\mathrm{M}_{3}$ receptors, respectively. We examined the amygdala, caudate putamen, dorsal hippocampus, motor cortex, retrosplenial cortex, and ventromedial hypothalamus. There were no significant group differences in any region for any muscarinic receptor type. These results suggest that removing peripheral ovarian hormones does not influence the cholinergic muscarinic receptor system in the context of PPI or receptor binding density.
\end{abstract}

Keywords: ovariectomy; female; rat; schizophrenia; PPI; CHRM1

\section{Introduction}

Current data suggest that female ovarian hormones can improve cognitive function [1-3] and reduce symptom severity in neuropsychiatric disorders, such as schizophrenia [4]. For instance, epidemiological evidence indicates that, compared to women, there is a higher incidence and earlier 
onset of schizophrenia in men [5]; the latter phenomenon is consistent across cultures and independent of the diagnostic classification system used [6-8]. There is also evidence to suggest that the impact of ovarian hormones on the symptoms of schizophrenia varies across the reproductive lifespan of women, which is underscored by changing levels of hormones, including the main ovarian hormones, estrogen and progesterone [8-10]. Overall, these factors lead to a less severe course of illness, milder symptoms, and superior treatment outcomes in women.

Cholinergic signaling plays a crucial role in multiple cognitive processes, including learning, memory, and sensory perception [11]. Converging lines of evidence have implicated muscarinic cholinergic signaling in the pathophysiology of schizophrenia. In patients with schizophrenia, in vivo muscarinic receptor availability was reduced [12,13], and postmortem radioligand binding studies using $\left[{ }^{3} \mathrm{H}\right]$-pirenzepine, which label muscarinic $\mathrm{M}_{1}$ and $\mathrm{M}_{4}$ receptors, have indicated that the densities of these receptors were decreased in the prefrontal cortex, anterior cingulate cortex, hippocampus, and caudate putamen of schizophrenia patients [14-18]. Notably, decreased levels of both $\mathrm{M}_{1}$ mRNA levels $[17,19,20]$ and $M_{1}$ receptor protein, but not $M_{2}, M_{3}$, or $M_{4}$ receptor protein [17,21], were observed in the dorsolateral prefrontal cortex and superior prefrontal gyrus from people with schizophrenia. These data suggest that low levels of cortical $\mathrm{M}_{1}$ receptors are a significant component of the pathophysiology of schizophrenia.

Scopolamine is a nonselective muscarinic receptor antagonist that induces a host of cognitive and psychotic symptoms referred to as "anti-muscarinic syndrome", which resembles some clinical aspects of schizophrenia [22,23]. In rodents, administration of scopolamine is known to induce deficits in prepulse inhibition (PPI) [24-26], which has been proposed as an antimuscarinic model of schizophrenia [27]. PPI is the attenuation of the acoustic startle response to an intense audiogenic stimulus (pulse) by a preceding, weaker acoustic stimulus (prepulse). PPI is used as an operational measure of sensorimotor gating, a process which is deficient in schizophrenia, and can be measured with analogous methods in rodents [28-30].

We and others have previously investigated the effects of ovariectomy, ovarian hormones, and their synthetic analogues in PPI [31-35]. For example, while ovariectomy had no effect on PPI [31-33], treatment with the estrogen, $17 \beta$-estradiol, could reverse PPI deficits that were induced by serotonin $1 \mathrm{~A}\left(5-\mathrm{HT}_{1 \mathrm{~A}}\right)$ receptor agonists in both female rats [32] and healthy women [36]. Specifically, chronic high-dose estradiol treatment prevented the disruptions in PPI induced by the $5-\mathrm{HT}_{1 \mathrm{~A}}$ receptor agonist 8-hydroxy-dipropylaminotertralin (8-OH-DPAT) in rats [32]. Similarly, estradiol treatment in healthy women abolished the deficits in PPI induced by the partial 5- $\mathrm{HT}_{1 \mathrm{~A}}$ receptor agonist, buspirone [36]. Subsequent pharmacological studies in rats indicated that chronic estradiol treatment inhibited the effects of $8-\mathrm{OH}-\mathrm{DPAT}$ and the dopamine $\mathrm{D}_{1} / \mathrm{D}_{2}$ receptor agonist, apomorphine, on PPI, and that the protective effects of estrogen on PPI were at least partly dependent on dopamine $\mathrm{D}_{2}$ receptor signaling down-stream of 5- $\mathrm{HT}_{1 \mathrm{~A}}$ receptor signaling [37]. Collectively, these findings implicate ovarian hormones, particularly estradiol, in the regulation of PPI. The impact of removal of ovarian hormones on PPI deficits induced by cholinergic muscarinic receptor agonists has not been previously examined.

Given that both muscarinic receptors and ovarian hormones are implicated in the mediation of PPI, the aim of this study was to assess the effects of ovariectomy on scopolamine-induced deficits in PPI and binding density of muscarinic receptors in the CNS in rats.

\section{Materials and Methods}

\subsection{Animals}

In total, 35 female Sprague-Dawley rats were used in this study. Rats were obtained from a commercial supplier (Animal Resources Centre; Perth, WA, Australia) when they were 9-10 weeks old and housed in open top cages in groups of 2-3 per cage with access to standard rat chow and water ad libitum. Rats were housed on a 12-hour light-dark cycle (lights on at 6 a.m.) at constant temperature of $23 \pm 2{ }^{\circ} \mathrm{C}$. All experimental procedures were approved by the Florey Institute of Neuroscience and 
Mental Health Animal Ethics Committee and were performed in accordance with the Australian Code of Practice for the Care and Use of Animals for Scientific Purposes.

\subsection{Ovariectomy}

At 11-12 weeks of age, rats were either left intact (sham-operated) or ovariectomized (OVX; $n=10$ per group) as reported previously [37]. For surgical procedures, rats were anaesthetized with isoflurane/oxygen gas mixture and injected with analgesic anti-inflammatory agent, carprofen (Rimadyl, Pfizer, $5 \mathrm{mg} / \mathrm{kg}$; West Ryde, NSW, Australia), to reduce postoperative pain. A 2-3 cm incision was made through the skin and abdominal wall on the lower medial region of the dorsal surface. The ovaries were located, and the ovaries were then bilaterally removed in the OVX rat group only. The wound was closed using two surgical sutures and covered with antiseptic cream (Betadine, povidone-iodine 10\%, Faulding Consumer; Salisbury, SA, Australia). Rats were given 10 days to recover before further experimentation.

\subsection{Prepulse Inhibition (PPI)}

PPI was measured using automated startle chambers (San Diego Instruments, San Diego, CA, USA), as described previously [37]. In brief, rats were placed in a transparent Plexiglas cylinder that sat within a sound-attenuating cabinet. Audiogenic stimuli were delivered with a speaker, and whole-body startle responses were measured using the automated SR-Lab software (San Diego Instruments). The 30-minute session consisted of 80 trials presented at variable intervals ( $8-27$ s), 8 no tone (i.e., only background, $70 \mathrm{~dB}$ ), 32 pulse-alone ( 4 blocks of $8 \times 115 \mathrm{~dB}$ ) trials, and 40 prepulse trials ( 8 of each: $2,4,8,12$, or $16 \mathrm{~dB}$ above background followed $100 \mathrm{~ms}$ later by the $115 \mathrm{~dB}$ pulse). Startle data were measured using all four blocks of pulse-alone trials. The percentage of PPI was calculated as the difference in amplitude between the startle response to the pulse-alone trials and the prepulse-pulse trials, divided by the response to the pulse-alone trial $\times 100 \%$.

Saline or $0.3 \mathrm{mg} / \mathrm{kg}$ scopolamine (Scopolamine hydrobromide trihydrate; Sigma-Aldrich, St. Louis, MO, USA) was administered subcutaneously $30 \mathrm{~min}$ prior to PPI testing. Scopolamine was dissolved in saline to a dose based on previous literature [25,38] and administered in a volume of $1 \mathrm{ml} / \mathrm{kg}$. Using a randomized, crossover protocol, rats received both treatments with 3-4 days allowed between each experiment.

\subsection{Autoradiography}

In a separate cohort of intact (sham-operated) $(n=7)$ or OVX $(n=8)$ rats (procedure as described above), frozen whole brains were blocked, and serial coronal $20 \mu \mathrm{m}$ sections were sectioned on a cryostat (Leica CM18-50, Leica Microsystems Nussloch GmbH, Germany) and thaw mounted onto gelatinized microscope slides. Sections were collected aiming for bregma $-2.76 \mathrm{~mm}$ [39], such that the following regions could be traced for the left and right hemispheres: retrosplenial cortex (granular and dysgranular), motor cortex (M1 and M2 combined), dorsal hippocampus, ventral caudate putamen, central amygdala, basolateral amygdala, medial amygdala, and ventromedial hypothalamus (Figure 1). Due to issues with sectioning and damaged tissue, we were unable to collect a measurement for each region for each rat, thus the final sample was $n=3-8$ per group.

Under the conditions used in this study, $\left[{ }^{3} \mathrm{H}\right]$-pirenzepine would provide a measure of $\mathrm{M}_{1}$ receptors [40], [ ${ }^{3} \mathrm{H}$ ]-AF-DX 384 would provide a measure of $\mathrm{M}_{2}$ and $\mathrm{M}_{4}$ receptors [41], and [ $\left.{ }^{3} \mathrm{H}\right]-4$-DAMP (4-diphenylacetoxy- $\mathrm{N}$-methylpiperidine methiodide) would provide a measure of $\mathrm{M}_{3}$ receptors [42]. For all three radioligands (PerkinElmer, Waltham, MA, USA), three sections per animal were used to measure total radioligand binding, and two sections per animal were used to measure nonspecific binding (Figure 2). 


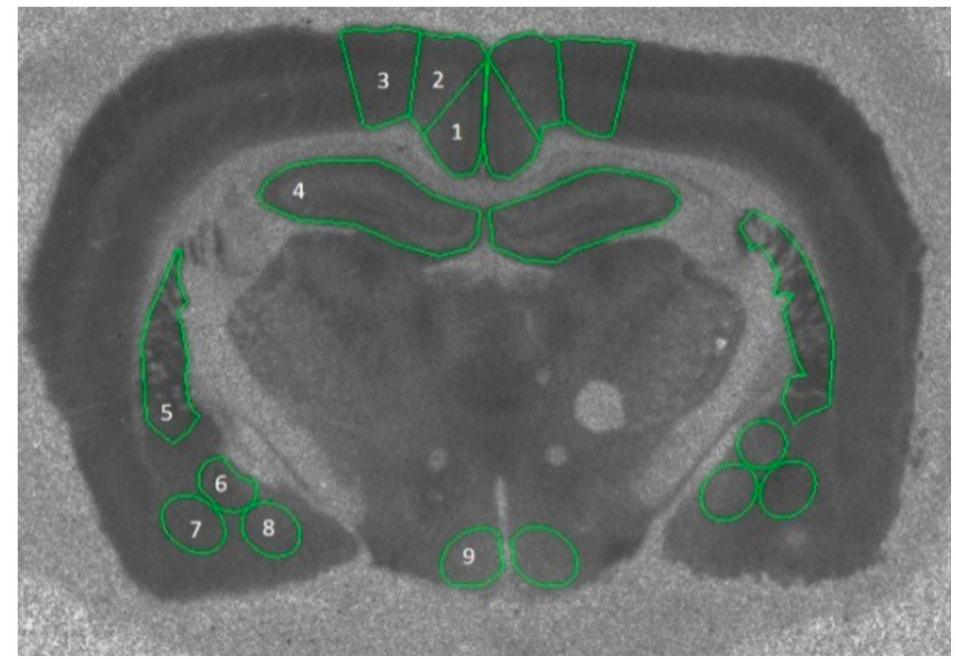

Figure 1. Example autoradiographic image of $\left[{ }^{3} \mathrm{H}\right]-\mathrm{AF}-\mathrm{DX}$ binding showing the traced outlines of the nine regions of interest: (1) retrosplenial cortex (granular), (2) retrosplenial cortex (dysgranular), (3) motor cortex (M1, M2), (4) dorsal hippocampus, (5) caudate putamen, (6) central amygdala, (7) basolateral amygdala, (8) medial amygdala, and (9) ventromedial hypothalamus.

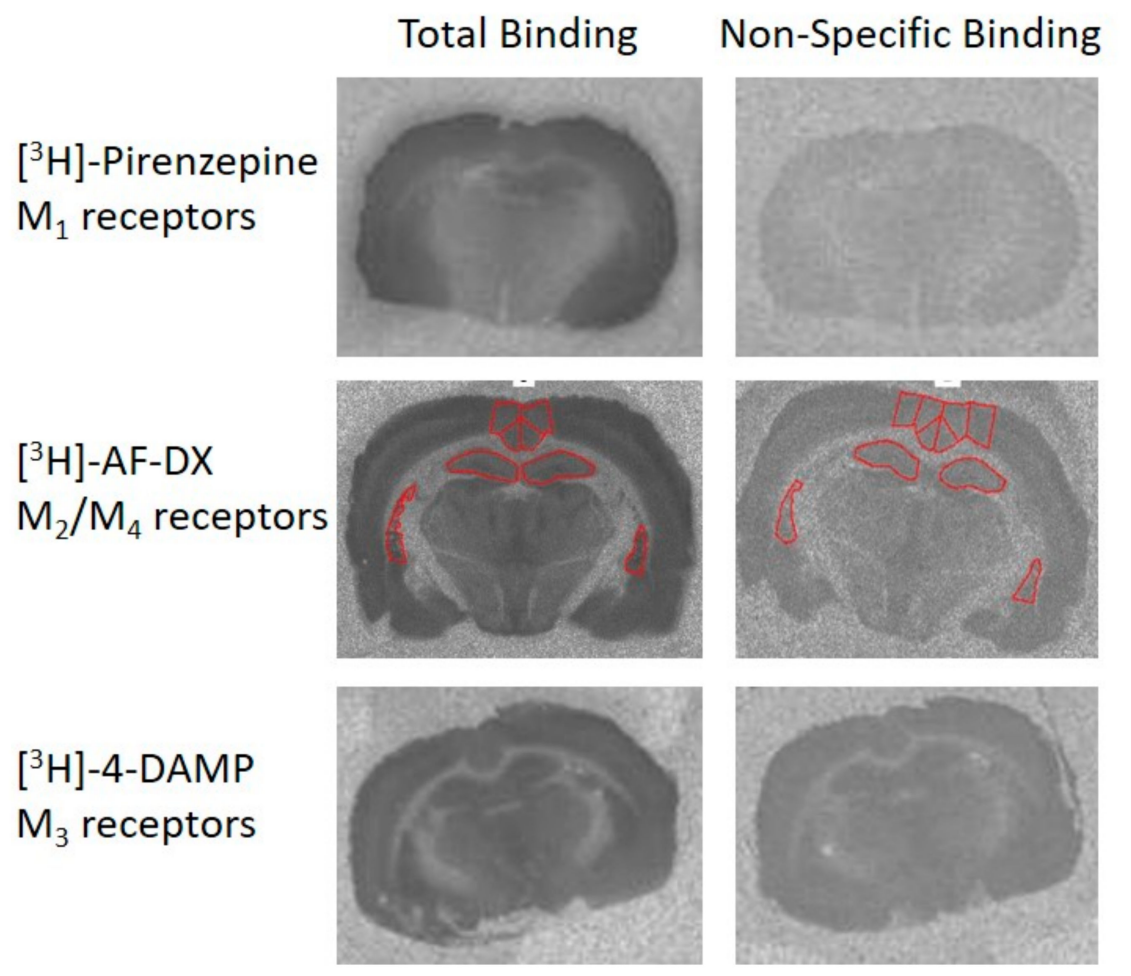

Figure 2. Representative autoradiographic images showing total binding (left panels) and nonspecific binding (right panels). Three tritiated radioligands were used with the protocols described in Section 2.4.

For $\left[{ }^{3} \mathrm{H}\right]$-pirenzepine binding, tissue sections were incubated in assay buffer $\left(10 \mathrm{mM} \mathrm{KH} \mathrm{PO}_{4}, 10\right.$ $\mathrm{mM} \mathrm{Na}_{2} \mathrm{HPO}_{4}$; $\mathrm{pH}$ 7.4) containing $25 \mathrm{nM}\left[{ }^{3} \mathrm{H}\right]$-pirenzepine in the presence or absence of $1 \mu \mathrm{M} \mathrm{QNX}$ (3-quinuclidinyl xanthene-9-carboxylate hemioxalate; Sigma-Aldrich) for $30 \mathrm{~min}$ at room temperature. $\left[{ }^{3} \mathrm{H}\right]$-AF-DX 384 binding was measured after incubating tissue sections in assay buffer $\left(10 \mathrm{mM} \mathrm{KH}_{2} \mathrm{PO}_{4}\right.$, $10 \mathrm{mM} \mathrm{Na}_{2} \mathrm{HPO}_{4} ; \mathrm{pH} 7.4$ ) for $30 \mathrm{~min}$ at room temperature. The tissue sections were then dipped in distilled water and air-dried. Sections were next incubated in assay buffer containing $24 \mathrm{nM}$ $\left[{ }^{3} \mathrm{H}\right]-\mathrm{AF}-\mathrm{DX} 384$ in the absence (total binding) or presence (nonspecific binding) of $1 \mu \mathrm{M}$ tropicamide 
(Tocris Bioscience, Bristol, UK) for $60 \mathrm{~min}$ at room temperature. For both radioligands, tissue sections were then washed twice for $2 \mathrm{~min}$ in ice-cold assay buffer, dipped in ice-cold distilled water, dried, partially fixed in paraformaldehyde vapor overnight, and then apposed to a BAS-TR2025 plate (Fujifilm, Tokyo, Japan) with autoradiographic tritium standards (American Radiolabeled Chemicals, St. Louis, $\mathrm{MO}, \mathrm{USA})$ for $3\left(\left[{ }^{3} \mathrm{H}\right]\right.$-pirenzepine) or $7\left(\left[{ }^{3} \mathrm{H}\right]-\mathrm{AF}-\mathrm{DX} 384\right)$ days.

For $\left[{ }^{3} \mathrm{H}\right]-4-D A M P$ binding, tissue sections were incubated in assay buffer $(50 \mathrm{mM}$ Tris- $\mathrm{HCl} ; \mathrm{pH} 7.4)$ for $15 \mathrm{~min}$ at room temperature, dipped in distilled water, and air-dried. Sections were then incubated in assay buffer containing $60 \mathrm{nM}\left[{ }^{3} \mathrm{H}\right]$-4-DAMP and $1 \mu \mathrm{M}$ pirenzepine dihydrochloride (to displace $\mathrm{M}_{1}$ receptors) in the absence (total binding) or presence (nonspecific binding) of $10 \mu \mathrm{M}$ 4-DAMP mustard for $60 \mathrm{~min}$ at room temperature. After radioligand binding, slides were washed twice for $5 \mathrm{~min}$ in ice-cold assay buffer, dipped in ice-cold distilled water, dried, partially fixed overnight in paraformaldehyde vapor, and apposed to a BAS-TR2025 plate with autoradiographic tritium standards for 3 days.

In all cases, the BAS-TR2025 plates were scanned in a BAS 5000 high resolution phosphoimager (Fujifilm, Tokyo, Japan). The resulting images were analyzed using AIS imaging software (Imaging Research, St. Catharines, ON, Canada). Radioligand binding was measured as an integrated measurement of signal intensity across the entire region of binding, including both hemispheres. Signal intensities were calibrated against the standards and expressed as the average amount of total bound radioligand ( $\mathrm{fmol} / \mathrm{mg}$ ) estimated tissue equivalent (ETE) minus the average nonspecific binding for each rat [43].

\subsection{Statistical Analysis}

All data are expressed as mean \pm standard error of the mean (S.E.M.) and were analyzed using IBM SPSS Statistics for Windows, Version 26 (IBM Corp., Armonk, NY, USA). Differences between groups were considered significant if $p<0.05$. Group differences in body and uterus weights were analyzed using unpaired $t$-tests. For PPI, a 2 group (intact, OVX) x 2 drug (saline, scopolamine) $\times$ 5 prepulse intensity (PP2-PP16) three-way repeated-measures analysis of variance (ANOVA) was used. For startle amplitude, a 2 group (intact, OVX) $\times 2$ drug (saline, scopolamine) $\times 4$ block $(4 \times$ 8 pulse-alone trials) three-way ANOVA was used. For graphical presentation only, average startle amplitudes were used. Group differences in muscarinic receptor binding density were analyzed using separate unpaired $t$-tests for each receptor in each brain region.

\section{Results}

\subsection{Ovariectomy}

At the time of surgery, body weights did not differ between the groups (Intact: $258 \pm 6 \mathrm{~g}$, OVX: $254 \pm 4 \mathrm{~g} ; t(18)=0.47, p=0.64)$. Consistent with our prior studies [37], at the end of experimentation, OVX rats had significantly greater body weight (Intact: $307 \pm 11$ g, OVX: $361 \pm 13$ g; $t(18)=-3.22, p=$ $0.005)$ than intact rats. OVX rats also had significantly smaller uteri when expressed as an absolute weight (Intact: $0.61 \pm 0.04 \mathrm{~g}$, OVX: $0.11 \pm 0.00 \mathrm{~g} ; t(18)=11.30, p<0.001$ ) or as a percentage of body weight (Intact: $0.20 \pm 0.01 \%$, OVX: $0.03 \pm 0.00 \% ; t(18)=11.33, p<0.001$ ). These findings confirmed the effectiveness of the OVX surgery.

\subsection{Prepulse Inhibition}

When comparing PPI in intact and OVX rats that were administered saline or $0.3 \mathrm{mg} / \mathrm{kg}$ scopolamine ( 2 group $\times 2$ dose $\times 5$ prepulse intensity ANOVA; Figure 3 ), the main effect of prepulse intensity was observed $(F(4,72)=94.18, p<0.001)$, reflecting an increase in PPI with increasing prepulse intensity. The main effect of drug was observed $(F(1,18)=51.20, p<0.001)$, reflecting the disruption of PPI caused by scopolamine treatment in intact rats $(F(1,9)=45.41, p<0.001)$ and OVX rats $(F(1,9)=15.49, p=$ 
0.003; Figure 3). No main effect of group, or any interactions of group and drug or prepulse intensity, were detected, reflecting a similar disruption in PPI in both groups.

A PPI of intact rats

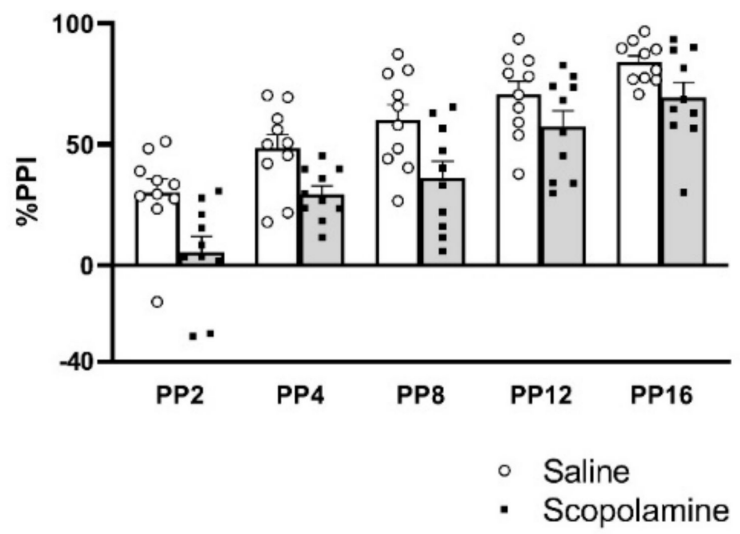

B PPI of OVX rats
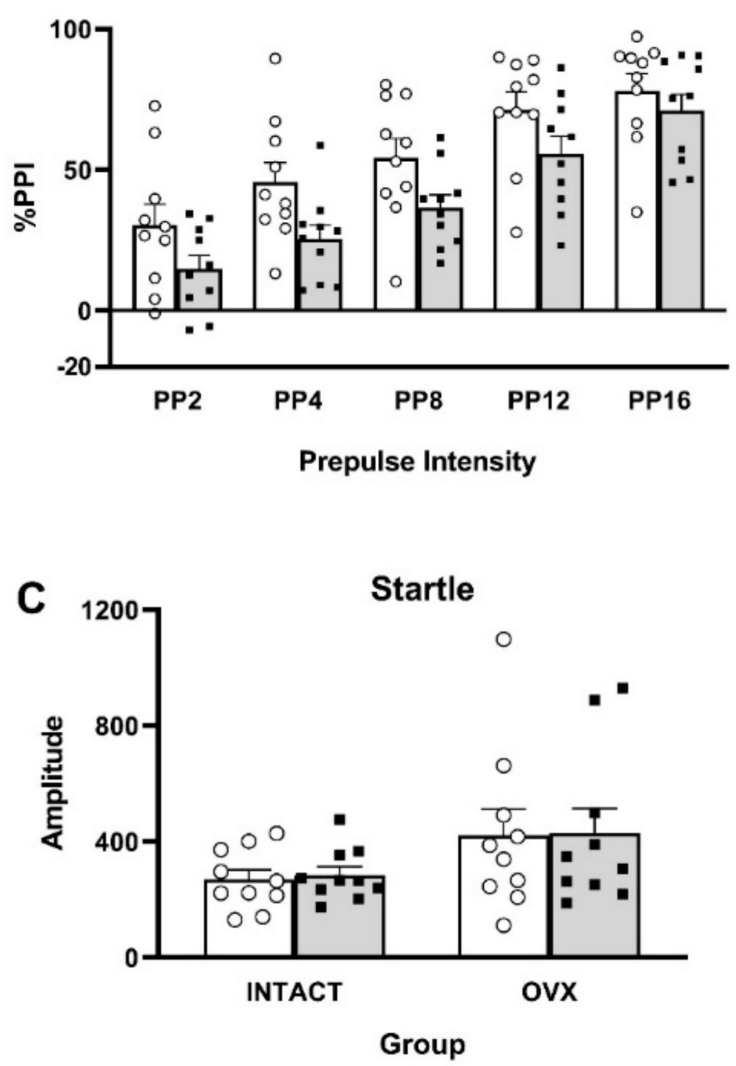

Figure 3. Prepulse inhibition (PPI; graphs A and B) and startle responses (graph C) in intact or ovariectomized (OVX) rats ( $n=10$ per group). Rats were tested after treatment with saline (white bars) or $0.3 \mathrm{mg} / \mathrm{kg}$ scopolamine (grey bars). Individual data are depicted by open circles (saline) or black squares (scopolamine). \%PPI refers to the difference in startle between the pulse-alone trials and the prepulse-pulse trials, divided by the response to the pulse-alone trial $\times 100 \%$. Prepulse intensity (PP) refers to the trials that were $2,4,8,12$, or $16 \mathrm{~dB}$ above the $70 \mathrm{~dB}$ background noise followed $100 \mathrm{~ms}$ later by the $115 \mathrm{~dB}$ startling pulse. Startle amplitude refers to the average of the four blocks of eight $115 \mathrm{~dB}$ startling pulses. Bars represent mean \pm S.E.M. 
When comparing startle amplitude between groups ( 2 group $\times 2$ drug $\times 4$ block ANOVA), no significant effects or interactions were observed, reflecting similar startle amplitudes in both groups, with or without scopolamine and over the duration of the PPI session (Figure 3). Thus, the PPI results were not affected by a change in startle amplitude.

\subsection{Receptor Binding Autoradiography}

There were no significant differences in $\left[{ }^{3} \mathrm{H}\right]$-pirenzepine, $\left[{ }^{3} \mathrm{H}\right]$-AF-DX, or $\left[{ }^{3} \mathrm{H}\right]-4$-DAMP binding density in any of the nine brain regions between intact and OVX rats (Table 1). A trend for reduced $\left[{ }^{3} \mathrm{H}\right]-A F-D X$ binding density was observed in the hippocampus of OVX rats compared to intact rats $(t(6)=2.30, p=0.061)$. There was also a trend for reduced $\left[{ }^{3} \mathrm{H}\right]-4$-DAMP binding density in the central amygdala of OVX rats compared to intact rats $(t(7)=2.19, p=0.065)$.

Table 1. Mean (S.E.M.) cholinergic muscarinic receptor binding density (fmol/mg estimated tissue equivalent) in intact and ovariectomized (OVX) rats in nine brain regions ( $n=3-8$ per group). $\left[{ }^{3} \mathrm{H}\right]$-Pirenzepine, $\left[{ }^{3} \mathrm{H}\right]$-AF-DX 384, and $\left[{ }^{3} \mathrm{H}\right]$-4-DAMP were used to label $\mathrm{M}_{1}, \mathrm{M}_{2} / \mathrm{M}_{4}$, and $\mathrm{M}_{3}$ receptors, respectively.

\begin{tabular}{ccccccc}
\hline & \multicolumn{2}{c}{$\left[{ }^{3} \mathbf{H}\right]-P i r e n z e p i n e$} & \multicolumn{2}{c}{$\left[{ }^{3} \mathbf{H}\right]-A F-D X$} & \multicolumn{2}{c}{$\left[{ }^{3} \mathbf{H}\right]-4-D A M P$} \\
\cline { 2 - 7 } & INTACT & OVX & INTACT & OVX & INTACT & OVX \\
\hline Retrosplenial cortex (granular) & $66.4(1.7)$ & $64.9(2.3)$ & $77.1(3.0)$ & $75.1(3.4)$ & $71.4(3.6)$ & $79.0(4.9)$ \\
Retrosplenial cortex (dysgranular) & $89.7(3.4)$ & $84.2(6.3)$ & $81.0(4.3)$ & $82.3(4.8)$ & $91.8(4.6)$ & $90.5(6.4)$ \\
Motor cortex (M1, M2) & $105.5(5.2)$ & $108.1(5.8)$ & $92.6(6.5)$ & $92.2(3.0)$ & $124.0(13.4)$ & $134.8(17.8)$ \\
Dorsal hippocampus & $93.3(14.4)$ & $82.2(11.4)$ & $71.9(2.6)$ & $61.2(4.4)$ & $82.2(5.8)$ & $76.6(3.3)$ \\
Caudate putamen (ventral) & $91.4(9.0)$ & $94.4(7.5)$ & $89.6(2.8)$ & $96.9(4.1)$ & $120.2(16.7)$ & $122.7(16.9)$ \\
Central amygdala & $97.5(9.7)$ & $82.3(2.2)$ & $68.2(2.6)$ & $60.7(4.4)$ & $78.1(2.4)$ & $65.8(4.6)$ \\
Basolateral amygdala & $126.3(7.5)$ & $114.2(2.5)$ & $96.7(7.4)$ & $90.5(6.6)$ & $77.8(5.1)$ & $81.6(6.6)$ \\
Medial amygdala & $73.0(3.1)$ & $70.3(3.1)$ & $58.1(2.4)$ & $54.5(3.1)$ & $72.4(5.2)$ & $61.8(4.7)$ \\
Ventromedial hypothalamus & $18.9(1.3)$ & $19.7(2.6)$ & $31.3(3.3)$ & $27.5(5.4)$ & - & - \\
\hline
\end{tabular}

\section{Discussion}

In this study, we aimed to investigate the effects of ovariectomy on scopolamine-induced PPI deficits and cholinergic muscarinic receptor binding density to assess potential interactions between ovarian hormones and muscarinic receptors. We did not observe any effects of ovariectomy on scopolamine-induced impairments in PPI, nor did we detect any significant changes in the binding density of $\mathrm{M}_{1}, \mathrm{M}_{2} / \mathrm{M}_{4}$, and $\mathrm{M}_{3}$ receptors in the amygdala, caudate putamen, dorsal hippocampus, motor cortex, retrosplenial cortex, or ventromedial hypothalamus of OVX rats relative to intact rats. These results suggest that muscarinic receptor antagonist-induced PPI deficits are independent of ovarian hormone status. To our knowledge, this study is the first to examine scopolamine-induced PPI deficits in female rats and to systematically assess the effects of eliminating circulating ovarian hormones on $\mathrm{M}_{1}, \mathrm{M}_{2} / \mathrm{M}_{4}$, and $\mathrm{M}_{3}$ receptor density in the female rat brain.

Past research has highlighted an interaction between estrogen and the muscarinic system. For instance, ovariectomy attenuates high-affinity choline uptake and acetylcholine synthesis in cerebral cortical synaptosomes [44]. Estrogen receptors are densely expressed in the basal forebrain, which provides major cholinergic input to the hypothalamus, hippocampus, and cortex [45,46]. Further, muscarinic receptor binding fluctuates across the estrous cycle [47], and ovariectomy upregulates $\mathrm{M}_{4}$ receptors in the hippocampus, frontal cortex, and hypothalamus, an effect that was normalized by estrogen, but not progesterone, treatment [48]. In humans, chronic estrogen therapy in women was associated with greater cholinergic responsivity and significantly higher $\mathrm{M}_{1}$ and $\mathrm{M}_{4}$ receptor density compared to that in women who were naïve to estrogen therapy $[49,50]$. Based on these findings, we hypothesized that removal of estrogen would modulate muscarinic receptor expression in nine specific brain regions, namely, the granular and dysgranular retrosplenial cortex; motor cortex; dorsal hippocampus; caudate putamen; amygdaloid regions including the central, basolateral, and medial nuclei; and ventromedial hypothalamus. These regions were selected for anatomical and 
functional reasons, as they express a high density of muscarinic receptors and are implicated in various sensorimotor and cognitive processes. For instance, the retrosplenial cortex plays a crucial role in spatial and episodic memory, navigation, and planning for the future [51]. The retrosplenial cortex receives dense cholinergic innervation from the basal forebrain, and the loss of such cholinergic inputs induces upregulation of muscarinic receptors in this region [52]. In the dorsal hippocampus, more than $90 \%$ of nonpyramidal/GABAergic neurons express muscarinic receptors [53]. Moreover, muscarinic receptor signaling in the dorsal hippocampus is critical for memory consolidation [54]. Indeed, muscarinic receptor levels are decreased in the hippocampal formation of schizophrenia patients relative to healthy controls [15], most likely due to low levels of $\mathrm{M}_{4}$ receptor expression [55], whilst [ $\left.{ }^{3} \mathrm{H}\right]-\mathrm{AF}-\mathrm{DX}$ binding is reduced in the caudate putamen of schizophrenia patients [41] in the absence of changes in $M_{1}$ and $M_{2}$ receptor expression [20]. The amygdaloid complex, especially the central amygdala, also expresses a high density of muscarinic receptors [56]. Estradiol treatment dose-dependently increased muscarinic receptor binding in the ventromedial hypothalamus of OVX female rats, whereas muscarinic receptor binding was not altered in vehicle-treated OVX female rats or estradiol-treated male rats [57]. Although the above literature highlights an interaction between estrogen and the muscarinic system, the precise role of estrogen and other ovarian hormones in cholinergic signaling is unclear and likely involves a complex modulatory role of ovarian hormones on multiple systems.

In the present study, we did not observe any significant changes in $M_{1}, M_{2} / M_{4}$, or $M_{3}$ receptor binding density in OVX rats relative to intact rats in any of the brain regions examined, suggesting that removal of ovarian hormones does not directly impact muscarinic receptor density in these brain regions in adult female rats. Studies have assessed the effects of ovariectomy on the expression of muscarinic receptor subtypes $\left(\mathrm{M}_{1}\right.$ to $\left.\mathrm{M}_{5}\right)$ but have largely focused on the rat hippocampus [58-60]. In contrast to our findings, one study reported that ovariectomy augmented the protein expression of all muscarinic receptor subtypes compared to control in whole hippocampal homogenates from Wistar rats [58]. Various methodological differences may explain this discrepancy; our study measured individual muscarinic receptors, in the dorsal hippocampus, using tissue sections from Sprague-Dawley rats. Nevertheless, we observed a trend for reduced $\mathrm{M}_{2} / \mathrm{M}_{4}$ receptor binding density in the hippocampus of OVX rats relative to intact rats. Pharmacological and behavioral studies have implicated the importance of $\mathrm{M}_{2}$ receptors in learning and memory task performance [61,62]. The trend for reduced hippocampal $\mathrm{M}_{2} / \mathrm{M}_{4}$ receptor binding partly supports past observations that ovariectomy affects hippocampal-dependent learning and memory in rats. Indeed, the positive effects of estrogen on working memory are dependent on $\mathrm{M}_{2}$ receptor hippocampal signaling [63].

In humans, ovarian hormones have been demonstrated to affect PPI [36], with lower PPI in females than in males, and reduced PPI in women during the luteal phase when circulating estradiol and progesterone are elevated [64-66]. We have previously demonstrated that estradiol treatment has a protective effect on disruptions of PPI induced by the 5- $\mathrm{HT}_{1 \mathrm{~A}}$ receptor agonist; $8-\mathrm{OH}-\mathrm{DPAT}$; and dopamine receptor agonist, apomorphine [32,36]. We therefore assessed whether removal of the major source of circulating estrogen would impact deficits in PPI induced by the nonselective muscarinic receptor antagonist, scopolamine. However, we did not observe any differences in scopolamine-induced deficits in PPI between OVX and intact rats. Our results suggest that scopolamine-induced impairments in PPI are not mediated by ovarian hormones, given that the elimination of circulating ovarian hormones did not significantly alter PPI. The absence of behavioral effects was consistent with the lack of alterations in muscarinic receptor binding density observed in this study. Ovariectomy removes the main source of estradiol, progesterone, and other ovarian hormones from the periphery. Thus, the lack of effect observed here could be due to the role of progesterone (or other hormones) masking the effects of estradiol, as progesterone could be exerting contrasting effects to those induced by estradiol [10]. Additionally, central production of these hormones may have partly compensated for the reduction in peripheral levels of these hormones. Further research is needed to determine the exact role of each ovarian hormone. It would also be of interest to determine if ovarian hormones influence muscarinic 
receptor activation, as the $\mathrm{M}_{1} / \mathrm{M}_{4}$ receptor agonist, xanomeline, has been shown to be efficacious in the treatment of schizophrenia [67].

A limitation of the binding results is that several tissue samples were damaged, and we were unable to collect a measurement for every single region in each rat. As such, group sample sizes were unequal and some groups had small sample size $(n=3-8)$, which limits the generalizability of these findings. Future research should repeat these experiments with larger sample sizes to increase statistical power and improve signal detection. Another limitation is that we did not control for estrous cycle stage in the control rats.

\section{Conclusions}

In conclusion, this study demonstrated that ovariectomy does not influence the cholinergic muscarinic receptor system in the context of PPI or receptor binding density. Our results suggest that removing peripheral ovarian hormones do not affect scopolamine-induced disruptions in PPI or muscarinic receptor binding density. Further, it is possible that ovarian hormones may have effects on cognition through pathways other than the cholinergic muscarinic receptor system.

Author Contributions: Conceptualization, A.G. (Andrea Gogos) and B.D.; methodology and validation, A.J.W., A.G. (Andrew Gibbons), M.U., and A.G. (Andrea Gogos); formal analysis, A.G. (Andrea Gogos) and A.J.W.; resources, A.G. (Andrea Gogos), B.D., and S.K.; data curation, A.J.W., M.M., T.-K.L., and N.T.; writing-original draft preparation, S.S.C., A.G. (Andrea Gogos), and M.M.; writing-review and editing, all authors; supervision, A.G. (Andrea Gogos), S.K., and B.D.; funding acquisition, A.G. (Andrea Gogos) and B.D. All authors have read and agreed to the published version of the manuscript.

Funding: This research was funded by the National Health and Medical Research Council of Australia, A.Gogos CDF ID1108098. A.J.W. was supported by a Trisno Family Fellowship. The Florey Institute of Neuroscience and Mental Health acknowledges the support from the Victorian Government's Operational Infrastructure Support Grant.

Conflicts of Interest: The authors declare no conflict of interest. The funders had no role in the design of the study; in the collection, analyses, or interpretation of data; in the writing of the manuscript; or in the decision to publish the results.

\section{References}

1. Dohanich, G. Ovarian steroids and cognitive function. Curr. Dir. Psychol. Sci. 2003, 12, 57-61. [CrossRef]

2. Gogos, A.; Wu, Y.C.; Williams, A.S.; Byrne, L.K. The effects of ethinylestradiol and progestins ("the pill") on cognitive function in pre-menopausal women. Neurochem. Res. 2014, 39, 2288-2300. [CrossRef]

3. Sbisa, A.M.; van den Buuse, M.; Gogos, A. The Effect of $17 \beta-E s t r a d i o l$ and Its Analogues on Cognition in Preclinical and Clinical Research: Relevance to Schizophrenia. In Psychiatry and Neuroscience Update-Vol. II; Springer: Berlin/Heidelberg, Germany, 2017; pp. 355-374.

4. Gogos, A.; Ney, L.J.; Seymour, N.; Van Rheenen, T.E.; Felmingham, K.L. Sex differences in schizophrenia, bipolar disorder, and post-traumatic stress disorder: Are gonadal hormones the link? Br. J. Pharmacol. 2019, 176, 4119-4135. [CrossRef]

5. McGrath, J.; Saha, S.; Welham, J.; El Saadi, O.; MacCauley, C.; Chant, D. A systematic review of the incidence of schizophrenia: The distribution of rates and the influence of sex, urbanicity, migrant status and methodology. BMC Med. 2004, 2, 13. [CrossRef]

6. Castle, D.J.; Abel, K.; Takei, N.; Murray, R.M. Gender differences in schizophrenia: Hormonal effect or subtypes? Schizophr. Bull. 1995, 21, 1-12. [CrossRef]

7. Häfner, H.; Riecher-Rössler, A.; Der Heiden, W.A.; Maurer, K.; Fätkenheuer, B.; Löffler, W. Generating and testing a causal explanation of the gender difference in age at first onset of schizophrenia. Psychol. Med. 1993, 23, 925-940. [CrossRef]

8. Gogos, A.; Sbisa, A.M.; Sun, J.; Gibbons, A.; Udawela, M.; Dean, B. A role for estrogen in schizophrenia: Clinical and preclinical findings. Int. J. Endocrinol. 2015, 2015, 615356. [CrossRef]

9. Seeman, M.V.; Lang, M. The role of estrogens in schizophrenia gender differences. Schizophr. Bull. 1990, 16, 185-194. [CrossRef] 
10. Sun, J.; Walker, A.J.; Dean, B.; Van den Buuse, M.; Gogos, A. Progesterone: The neglected hormone in schizophrenia? A focus on progesterone-dopamine interactions. Psychoneuroendocrinology 2016, 74, 126-140. [CrossRef]

11. Sarter, M.; Parikh, V. Choline transporters, cholinergic transmission and cognition. Nat. Rev. Neurosci. 2005, 6, 48. [CrossRef]

12. Raedler, T.J.; Knable, M.B.; Jones, D.W.; Urbina, R.A.; Gorey, J.G.; Lee, K.S.; Egan, M.F.; Coppola, R.; Weinberger, D.R. In vivo determination of muscarinic acetylcholine receptor availability in schizophrenia. Am. J. Psychiatry 2003, 160, 118-127. [CrossRef] [PubMed]

13. Raedler, T.J.; Knable, M.B.; Jones, D.W.; Lafargue, T.; Urbina, R.A.; Egan, M.F.; Pickar, D.; Weinberger, D.R. In vivo olanzapine occupancy of muscarinic acetylcholine receptors in patients with schizophrenia. Neuropsychopharmacology 2000, 23, 56. [CrossRef]

14. Dean, B.; Crook, J.; Opeskin, K.; Hill, C.; Keks, N.; Copolov, D. The density of muscarinic M1 receptors is decreased in the caudate-putamen of subjects with schizophrenia. Mol. Psychiatry 1996, 1, 54-58.

15. Crook, J.M.; Tomaskovic-Crook, E.; Copolov, D.L.; Dean, B. Decreased muscarinic receptor binding in subjects with schizophrenia: A study of the human hippocampal formation. Biol. Psychiatry 2000, 48, 381-388. [CrossRef]

16. Crook, J.M.; Tomaskovic-Crook, E.; Copolov, D.L.; Dean, B. Low muscarinic receptor binding in prefrontal cortex from subjects with schizophrenia: A study of Brodmann's areas 8, 9, 10, and 46 and the effects of neuroleptic drug treatment. Am. J. Psychiatry 2001, 158, 918-925. [CrossRef]

17. Dean, B.; McLeod, M.; Keriakous, D.; McKenzie, J.; Scarr, E. Decreased muscarinic 1 receptors in the dorsolateral prefrontal cortex of subjects with schizophrenia. Mol. Psychiatry 2002, 7, 1083. [CrossRef]

18. Katerina, Z.; Andrew, K.; Filomena, M.; Xu-Feng, H. Investigation of $\mathrm{m} 1 / \mathrm{m} 4$ muscarinic receptors in the anterior cingulate cortex in schizophrenia, bipolar disorder, and major depression disorder. Neuropsychopharmacology 2004, 29, 619. [CrossRef]

19. Mancama, D.; Arranz, M.; Landau, S.; Kerwin, R. Reduced expression of the muscarinic 1 receptor cortical subtype in schizophrenia. Am. J. Med Genet. Part B Neuropsychiatric Genet. 2003, 119, 2-6. [CrossRef]

20. Dean, B.; Crook, J.; Pavey, G.; Opeskin, K.; Copolov, D. Muscarinic 1 and 2 receptor mRNA in the human caudate-putamen: No change in $\mathrm{m} 1 \mathrm{mRNA}$ in schizophrenia. Mol. Psychiatry 2000, 5, 203. [CrossRef]

21. Scarr, E.; Keriakous, D.; Crossland, N.; Dean, B. No change in cortical muscarinic M2, M3 receptors or [35S]GTPgammaS binding in schizophrenia. Life Sci. 2006, 78, 1231-1237. [CrossRef]

22. Marchlewski, M.B. Anticholinergic syndrome: Avoiding misdiagnosis. J. Psychosoc. Nurs. Ment. Health Serv. 1994, 32, 22-24. [PubMed]

23. Perry, E.; Perry, R. Acetylcholine and hallucinations-disease-related compared to drug-induced alterations in human consciousness. Brain Cogn. 1995, 28, 240-258. [CrossRef] [PubMed]

24. Jones, C.K.; Shannon, H.E. Effects of scopolamine in comparison with apomorphine and phencyclidine on prepulse inhibition in rats. Eur. J. Pharmacol. 2000, 391, 105-112. [CrossRef]

25. Jones, C.K.; Shannon, H.E. Muscarinic cholinergic modulation of prepulse inhibition of the acoustic startle reflex. J. Pharmacol. Exp. Ther. 2000, 294, 1017-1023.

26. Geyer, M.A.; Krebs-Thomson, K.; Braff, D.L.; Swerdlow, N.R. Pharmacological studies of prepulse inhibition models of sensorimotor gating deficits in schizophrenia: A decade in review. Psychopharmacology 2001, 156, 117-154. [CrossRef]

27. Barak, S. Modeling cholinergic aspects of schizophrenia: Focus on the antimuscarinic syndrome. Behav. Brain Res. 2009, 204, 335-351. [CrossRef]

28. Braff, D.L.; Grillon, C.; Geyer, M.A. Gating and habituation of the startle reflex in schizophrenic patients. Arch. Gen. Psychiatry 1992, 49, 206-215. [CrossRef]

29. McGhie, A.; Chapman, J. Disorders of attention and perception in early schizophrenia. Br. J. Med Psychol. 1961, 34, 103-116. [CrossRef]

30. Van den Buuse, M. Modeling the positive symptoms of schizophrenia in genetically modified mice: Pharmacology and methodology aspects. Schizophr. Bull. 2009, 36, 246-270. [CrossRef]

31. Van den Buuse, M.; Eikelis, N. Estrogen increases prepulse inhibition of acoustic startle in rats. Eur. J. Pharmacol. 2001, 425, 33-41. [CrossRef] 
32. Gogos, A.; van den Buuse, M. Estrogen and progesterone prevent disruption of prepulse inhibition by the serotonin-1A receptor agonist 8-hydroxy-2-dipropylaminotetralin. J. Pharmacol. Exp. Ther. 2004, 309, 267-274. [CrossRef] [PubMed]

33. Gogos, A.; van den Buuse, M. Comparing the effects of $17 \mathrm{beta}$-oestradiol and the selective oestrogen receptor modulators, raloxifene and tamoxifen, on prepulse inhibition in female rats. Schizophr Res. 2015, 168, 634-639. [CrossRef] [PubMed]

34. Sbisa, A.; van den Buuse, M.; Gogos, A. The effect of estrogenic compounds on psychosis-like behaviour in female rats. PLoS ONE 2018, 13, e0193853. [CrossRef] [PubMed]

35. Georgiou, P.; Zanos, P.; Jenne, C.E.; Gould, T.D. Sex-Specific Involvement of Estrogen Receptors in Behavioral Responses to Stress and Psychomotor Activation. Front Psychiatry 2019, 10, 81. [CrossRef]

36. Gogos, A.; Nathan, P.J.; Guille, V.; Croft, R.J.; Van den Buuse, M. Estrogen prevents 5-HT 1A receptor-induced disruptions of prepulse inhibition in healthy women. Neuropsychopharmacology 2006, 31, 885. [CrossRef]

37. Gogos, A.; Kwek, P.; Chavez, C.; Van den Buuse, M. Estrogen treatment blocks 8-hydroxy-2-dipropylaminotetralin-and apomorphine-induced disruptions of prepulse inhibition: Involvement of dopamine D1 or D2 or serotonin 5-HT1A, 5-HT2A, or 5-HT7 receptors. J. Pharmacol. Exp. Ther. 2010, 333, 218-227. [CrossRef]

38. Andrus, A.K.; Marable, B.R.; Dunbar, G.L.; Reilly, M.P.; Maurissen, J.P. Effects of intensity and type of prepulse stimulus on prepulse inhibition in scopolamine treated rats. Pharmacol. Biochem. Behav. 2007, 87, 481-488. [CrossRef]

39. Paxinos, G.; Watson, C. The Rat Brain in Stereotaxic Coordinates; Elsevier: Amsterdam, The Netherlands, 2006.

40. Scarr, E.; Dean, B. Muscarinic receptors: Do they have a role in the pathology and treatment of schizophrenia? J. Neurochem. 2008, 107, 1188-1195. [CrossRef]

41. Crook, J.M.; Dean, B.; Pavey, G.; Copolov, D. The binding of $[3 \mathrm{H}]$ AF-DX 384 is reduced in the caudate-putamen of subjects with schizophrenia. Life Sci. 1999, 64, 1761-1771. [CrossRef]

42. Jeon, W.J.; Gibbons, A.S.; Dean, B. The use of a modified [3H]4-DAMP radioligand binding assay with increased selectivity for muscarinic M3 receptor shows that cortical CHRM3 levels are not altered in mood disorders. Prog. Neuro-Psychopharmacol. Biol. Psychiatry 2013, 47, 7-12. [CrossRef]

43. Pavey, G.M.; Copolov, D.L.; Dean, B. High-resolution phosphor imaging: Validation for use with human brain tissue sections to determine the affinity and density of radioligand binding. J. Neurosci. Methods 2002, 116, 157-163. [CrossRef]

44. O'Malley, C.A.; Hautamaki, R.D.; Kelley, M.; Meyer, E.M. Effects of ovariectomy and estradiol benzoate on high affinity choline uptake, ACh synthesis, and release from rat cerebral cortical synaptosomes. Brain Res. 1987, 403, 389-392. [CrossRef]

45. Toran-Allerand, C.D.; Miranda, R.C.; Bentham, W.; Sohrabji, F.; Brown, T.J.; Hochberg, R.B.; MacLusky, n.J. Estrogen receptors colocalize with low-affinity nerve growth factor receptors in cholinergic neurons of the basal forebrain. Proc. Natl. Acad. Sci. USA 1992, 89, 4668-4672. [CrossRef]

46. Newton-Mann, E.; Finney, C.; Purves-Tyson, T.; Gogos, A. Estrogen Receptors: Mechanism of Action and Relevance to Schizophrenia. Current Psychiatry Rev. 2017, 13, 55-64. [CrossRef]

47. Van Huizen, F.; March, D.; Cynader, M.S.; Shaw, C. Muscarinic receptor characteristics and regulation in rat cerebral cortex: Changes during development, aging and the oestrous cycle. Eur. J. Neurosci. 1994, 6, 237-243. [CrossRef]

48. El-Bakri, N.K.; Adem, A.; Suliman, I.; Mulugeta, E.; Karlsson, E.; Lindgren, J.; Winblad, B.; Islam, A. Estrogen and progesterone treatment: Effects on muscarinic M4 receptor subtype in the rat brain. Brain Res. 2002, 948, 131-137. [CrossRef]

49. Van Amelsvoort, T.; Murphy, D.; Robertson, D.; Daly, E.; Whitehead, M.; Abel, K. Effects of long-term estrogen replacement therapy on growth hormone response to pyridostigmine in healthy postmenopausal women. Psychoneuroendocrinology 2003, 28, 101-112. [CrossRef]

50. Norbury, R.; Travis, M.J.; Erlandsson, K.; Waddington, W.; Ell, P.J.; Murphy, D.G. Estrogen therapy and brain muscarinic receptor density in healthy females: A SPET study. Horm. Behav. 2007, 51, 249-257. [CrossRef]

51. Vann, S.D.; Aggleton, J.P.; Maguire, E.A. What does the retrosplenial cortex do? Nat. Rev. Neurosci. 2009, 10, 792. [CrossRef] 
52. Gage, S.L.; Keim, S.R.; Simon, J.R.; Low, W.C. Cholinergic innervation of the retrosplenial cortex via the fornix pathway as determined by high affinity choline uptake, choline acetyltransferase activity, and muscarinic receptor binding in the rat. Neurochem. Res. 1994, 19, 1379-1386. [CrossRef]

53. Van der Zee, E.; Luiten, P. GABAergic neurons of the rat dorsal hippocampus express muscarinic acetylcholine receptors. Brain Res. Bull. 1993, 32, 601-609. [CrossRef]

54. Ferreira, A.R.; Fürstenau, L.; Blanco, C.; Kornisiuk, E.; Sánchez, G.; Daroit, D.; e Silva, M.C.; Cerveñansky, C.; Jerusalinsky, D.; Quillfeldt, J.A. Role of hippocampal M1 and M4 muscarinic receptor subtypes in memory consolidation in the rat. Pharmacol. Biochem. Behav. 2003, 74, 411-415. [CrossRef]

55. Scarr, E.; Sundram, S.; Keriakous, D.; Dean, B. Altered hippocampal muscarinic M4, but not M1, receptor expression from subjects with schizophrenia. Biol. Psychiatry 2007, 61, 1161-1170. [CrossRef]

56. Van der Zee, E.; Roozendaal, B.; Bohus, B.; Koolhaas, J.; Luiten, P. Muscarinic acetylcholine receptor immunoreactivity in the amygdala-I. Cellular distribution correlated with fear-induced behavior. Neuroscience 1996, 76, 63-73. [CrossRef]

57. Dohanich, G.P.; Witcher, J.A.; Weaver, D.R.; Clemens, L.G. Alteration of muscarinic binding in specific brain areas following estrogen treatment. Brain Res. 1982, 241, 347-350. [CrossRef]

58. Cardoso, C.C.; Ricardo, V.P.; Frussa-Filho, R.; Porto, C.S.; Abdalla, F.M.F. Effects of $17 \beta$-estradiol on expression of muscarinic acetylcholine receptor subtypes and estrogen receptor $\alpha$ in rat hippocampus. Eur. J. Pharmacol. 2010, 634, 192-200. [CrossRef]

59. Cardoso, C.C.; Pereira, R.T.; Koyama, C.A.; Porto, C.S.; Abdalla, F.M. Effects of estrogen on muscarinic acetylcholine receptors in the rat hippocampus. Neuroendocrinology 2004, 80, 379-386. [CrossRef]

60. Pereira, R.T.; Porto, C.S.; Godinho, R.O.; Abdalla, F.M. Effects of estrogen on intracellular signaling pathways linked to activation of muscarinic acetylcholine receptors and on acetylcholinesterase activity in rat hippocampus. Biochem. Pharmacol. 2008, 75, 1827-1834. [CrossRef]

61. Carey, G.J.; Billard, W.; Binch, H., III; Cohen-Williams, M.; Crosby, G.; Grzelak, M.; Guzik, H.; Kozlowski, J.A.; Lowe, D.B.; Pond, A.J. SCH 57790, a selective muscarinic M2 receptor antagonist, releases acetylcholine and produces cognitive enhancement in laboratory animals. Eur. J. Pharmacol. 2001, 431, 189-200. [CrossRef]

62. Seeger, T.; Fedorova, I.; Zheng, F.; Miyakawa, T.; Koustova, E.; Gomeza, J.; Basile, A.S.; Alzheimer, C.; Wess, J. M2 muscarinic acetylcholine receptor knock-out mice show deficits in behavioral flexibility, working memory, and hippocampal plasticity. J. Neurosci. 2004, 24, 10117-10127. [CrossRef]

63. Daniel, J.M.; Hulst, J.L.; Lee, C.D. Role of hippocampal M2 muscarinic receptors in the estrogen-induced enhancement of working memory. Neuroscience 2005, 132, 57-64. [CrossRef]

64. Abel, K.; Waikar, M.; Pedro, B.; Hemsley, D.; Geyer, M. Repeated testing of prepulse inhibition and habituation of the startle reflex: A study in healthy human controls. J. Psychopharmacol. 1998, 12, 330-337. [CrossRef]

65. Swerdlow, N.R.; Auerbach, P.; Monroe, S.M.; Hartston, H.; Geyer, M.A.; Braff, D.L. Men are more inhibited than women by weak prepulses. Biol. Psychiatry 1993, 34, 253-260. [CrossRef]

66. Swerdlow, N.R.; Hartman, P.L.; Auerbach, P.P. Changes in sensorimotor inhibition across the menstrual cycle: Implications for neuropsychiatric disorders. Biol. Psychiatry 1997, 41, 452-460. [CrossRef]

67. Shekhar, A.; Potter, W.Z.; Lightfoot, J.; Lienemann, J.; Dube, S.; Mallinckrodt, C.; Bymaster, F.P.; McKinzie, D.L.; Felder, C.C. Selective muscarinic receptor agonist xanomeline as a novel treatment approach for schizophrenia. Am. J. Psychiatry 2008, 165. [CrossRef]

(C) 2020 by the authors. Licensee MDPI, Basel, Switzerland. This article is an open access article distributed under the terms and conditions of the Creative Commons Attribution (CC BY) license (http://creativecommons.org/licenses/by/4.0/). 